\title{
On-farm pre-weaning growth performance of Washera, Farta and their crossbred lambs in selected districts of western Amhara Region, Ethiopia
}

\author{
Esubalew Adimasu ${ }^{1,}$, , Kefyalew Alemayehu ${ }^{1}$, and Tesfaye Getachew ${ }^{2}$ \\ ${ }^{1}$ Bahir Dar University, Department of Animal Production and Technology, College of \\ Agriculture and Environmental Science, P.O. Box 5501, Bahir Dar, Ethiopia \\ ${ }^{2}$ International Center for Agricultural Research in the Dry Areas (ICARDA), Addis \\ Ababa, Ethiopia
}

\begin{abstract}
The objective of the study was to evaluate the pre-weaning growth performance of Farta, Washera, and their cross-sheep lambs. The study was conducted in Farta and Lay Gayint districts of the Amhara National Regional State. The data were collected from November 2016 to May 2017. A total of 132 sheep, i.e., 82 Farta, 20 Washera, and 30 Washera-Farta crossbred, were selected using purposive sampling technique to assess their pre-weaning growth performance. Growth data was analyzed using SAS Version 9.1.3. (SAS, 2008). Mean birth weight ( $\pm \mathrm{SE}$ in $\mathrm{kg}$ ) was $2.7 \pm 0.30$ for Farta, $3.1 \pm 0.14$ for Washera, and $2.9 \pm 0.08$ for Washera-Farta crossbred lambs. Weaning weights were $10.9 \pm 0.30 \mathrm{~kg}$ for Farta, $13.1 \pm 0.50 \mathrm{~kg}$ for Washera, and $12.2 \pm 1.1 \mathrm{~kg}$ for Washera-Farta crossbreds. Daily weight gain calculated from birth to 30 days was $89.4 \pm 6.44 \mathrm{~g}$ for Farta, $119.4 \pm 23.53 \mathrm{~g}$ for Washera and $111.4 \pm 10.46 \mathrm{~g}$ for Washera-Farta crossbreds. Weight gain from birth to 90 days was $88.8 \pm 3.21 \mathrm{~g}, 103.2 \pm 11.75 \mathrm{~g}$, and $111.9 \pm 5.22 \mathrm{~g}$, respectively. Washera breed was significantly heavier at birth and at weaning age, followed by crossbred lambs. Crossbred lambs were not significantly bigger than Farta lambs. This means crossing the two breeds did not have advantage and selection breeding of Farta sheep by itself will be adequate.
\end{abstract}

Keywords: Body weight, Crossbred sheep, Farta sheep, Washera sheep

DOI: https://dx.doi.org/10.4314/ejst.v11i3.4

\section{INTRODUCTION}

Ethiopia has about 30 million heads of sheep from which nearly $72 \%$ are females, and $28 \%$ are males. From the total number of sheep, $99.7 \%$ were indigenous while the rest is exotic and hybrid breeds (CSA, 2017).

\footnotetext{
"Correspondence author: Esubalew Adimasu, email: esubie2013@gmail.com
} 
Ethiopian existing breeds are adapted to the country's environmental conditions, i.e., scarce feedstuff and disease challenges (Solomon Gizaw et al., 2008). The demand from both domestic and export markets for animal products (small ruminants), especially mutton, is increasing in Ethiopia (SPS-LMM, 2010). The productivity of indigenous sheep is currently too low to meet this demand (Amha Sebsibe, 2008). Apparently, improving the productivity of sheep creates wealth and improves the living standards of smallholder farmers. At the same time, it is essential to meet the high meat demand of the country (Mesfin Lakew et al., 2014).

Small ruminants account for $40 \%$ of cash income earned by farm households, $19 \%$ of the total value of subsistence food derived from all livestock production and $25 \%$ of total domestic meat consumption (Adane Hirpa and Girma Abebe, 2008). Smallholder sheep production is the major source of food security serving a diverse function, including cash income, savings, fertilizer, socio-cultural functions and fiber production. Sheep are particularly important for farmers in the subalpine highlands as well as for pastoralists and agro-pastoralists where crop production is unreliable. Smallholder sheep production systems in the highland area is characterized by erratic and unevenly distributed rainfall, recurrent drought and scarce and poor-quality livestock feed (Solomon Bogle et al., 2008). In those production environments, crop failures recur and therefore the role of sheep in supporting the livelihood of smallholder farmers increases (Likawent Yeheyis et al., 2004; Markos Tibbo, 2006). However, the sheep flocks are managed under traditional extensive systems with no or with minimal inputs and without improved technologies, which result in low productivity (average body weight gain). Considered as one of the options, crossbreeding is a potentially attractive breed improvement method due to its quick benefits as the result of breed complementarity and heterotic effects (Hayes et al., 2009). Burrow (2012) also suggested a combination of multiple breeds to achieve the optimum level of production. The growth performance of sheep is influenced by age of the dam, the pre-mating weight of the dam, type of birth, sex, breed and season of birth (Solomon Gizaw et al., 2011). The growth performance of sheep is an important characteristic which determines the overall productivity of the flock and the economic return 
from sheep production enterprises with the objective of meat production. Increased economic returns from sheep production require improvements in the market weight of lambs to market age (Mengistu Taye et al., 2010).

In Ethiopia, attempts have been made to improve the productivity of indigenous sheep through crossing with exotic breeds such as Corriedale, Hampshire, Romney, Awassi and Dorper (Solomon Gizaw and Tesfaye Getachew, 2009). However, these programs have not been successful, probably because of lack of understanding of the preferred breeding objectives of the farmers and of the absence of involvement of all stakeholders in the designing of breeding strategies (Markos Tibbo et al., 2006, Gemeda Duguma et al., 2010). Such efforts have invariably been unsuccessful or unsustainable in the long term due to the incompatibility of the genotypes with the breeding objectives, management approaches and environmental conditions prevailing in low-input traditional production systems (Kosgey et al., 2006).

Ethiopia's Washera breed enjoys high growth rate and better twinning rates as its desirable traits (Mengistie Taye et al., 2011). To improve the productivity of medium-sized Farta sheep, Washera rams have been distributed to smallholder farmers throughout the Amhara Region (Tesfaye Getachew et al., 2009). The objective of this study was to assess birth weight, weaning weight and average daily weight gain of Farta, Washera and Washera-Farta crossbred lambs under farmer management systems.

\section{MATERIALS AND METHODS}

\section{Description of the study area}

Data on pre-weaning performances of lambs were collected from Farta and Lay Gayint districts of South Gondar Zone, western Amhara Regional State. According to the traditional agroecological classification, the study districts could be classified into midland and highland. According to FAO (2006) an altitude that ranges between 1500-2300 m a.s. 1 is considered as midland and above 2300 m.a.s.l as highland (Table 1, Figure 1). 


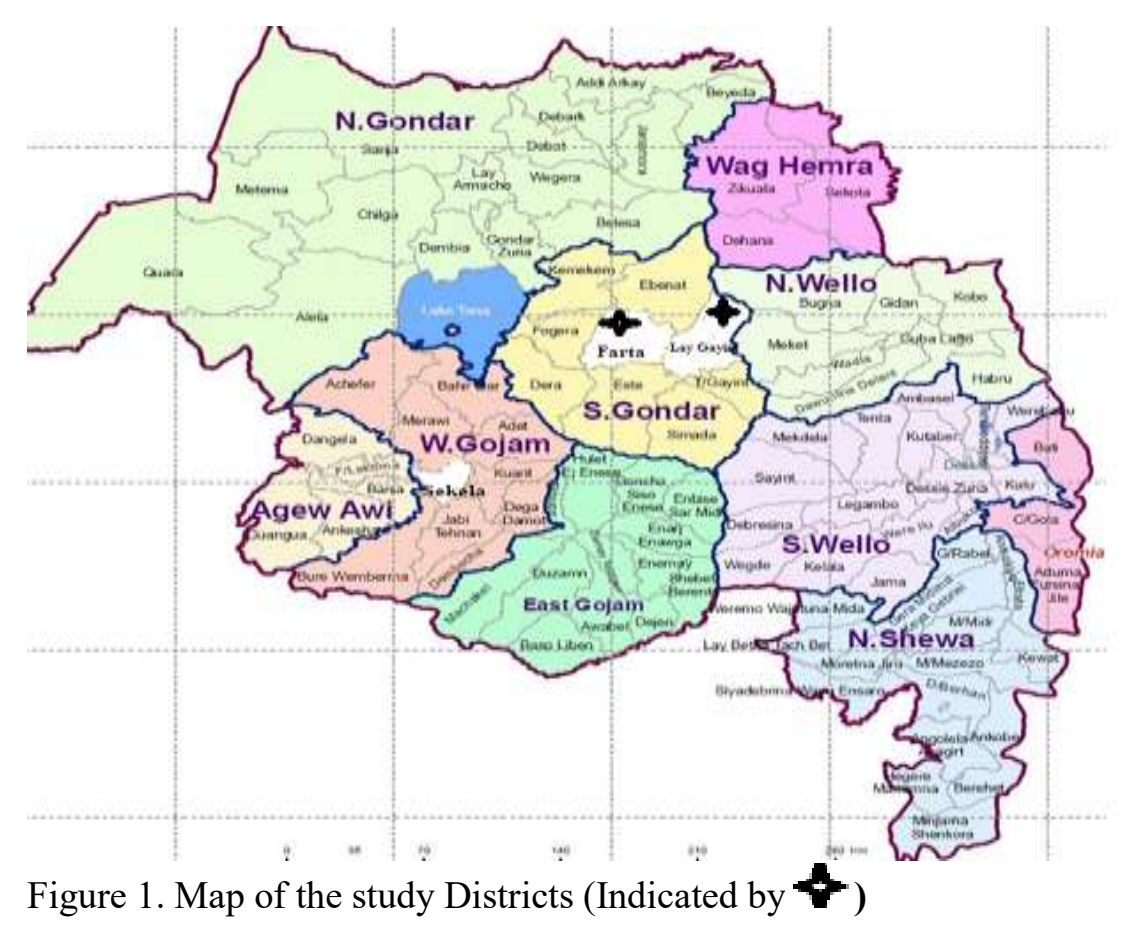


Table 1. Description of Farta and Lay Gayint districts

\begin{tabular}{lcc}
\hline Features & Farta & Lay Gayint \\
\hline Attitude $(\mathrm{m})$ & 1920 to 4135 & 1300 to 3500 \\
Temperature $\left({ }^{\circ} \mathrm{C}\right)$ & 9 to 25 & 9 to 19 \\
Rainfall $(\mathrm{mm})$ & 900 to 1099 & 600 to 1100 \\
& & \\
Human population & 232,181 & 206,499 \\
& & \\
Longitude & Geographic coordinates & \\
Latitude & $37^{\circ} 31^{\prime}-38^{\circ} 19^{\prime}$ & $38^{\circ} 12^{\prime}-38^{\circ} 19^{\prime}$ \\
& $11^{\circ} 32^{\prime}-12^{\circ} 03^{\prime}$ & $11^{\circ} 32^{\prime}-12^{\circ} 16^{\prime}$ \\
& & \\
Frost $(\%)$ & Agroecology & \\
Mountain $(\%)$ & 1.5 & 2.7 \\
Midland $(\%)$ & 42.5 & 45.4 \\
Low land $(\%)$ & 56.0 & 39.4 \\
Sheep & 0.0 & 12.5 \\
Goat & Animal population & 88,836 \\
\hline
\end{tabular}

Source: Respective District Agricultural Offices (2016)

\section{Description of study breeds}

Washera. Washera breed is desribed as short fat tailed, short-haired, large body sized, predominantly brown, and both males and females polled. The breed is distributed in West Gojam, East Gojam and Awi zones of the Amhara Regional State, and in Dangur, Mandura and Alefa Takusa districts reared by the Amhara and Agew communities (Solomon Gizaw et al., 2010). The growth rate after weaning is better than most of the indigenous breeds and it is comparable to some of the breeds like Horro and Bonga which are recognized as large-sized sheep breeds in Ethiopia. The literature mentions the good potential of this breed for 
commercial mutton production for the local and export markets. Washera sheep is also known for its relatively high twinning rate (Solomon Gizaw et al., 2013).

Farta sheep. Farta sheep is described as short fat tailed, wooly undercoat, medium size, coat color of white (37.5\%), brown (27.5\%) and black with a brown belly (15\%), white/brown with brown/white patches, and males are horned. It is distributed in South Gondar Zone, Gondar Zuria, Belesa, Dembia districts and it is reared by Amhara communities (Solomon Gizaw et al., 2010).

Washera-Farta crossbred sheep. This is a crossbreed of Washera and Farta sheep resulted from Washera rams and ewes introduced/distributed in South Gondar Zone (Farta and Lay Gayint districts) to improve the productivity of Farta sheep.

\section{Study animals and management}

Since 1983, different stakeholders introduced Washera breed into Farta and Lay Gayint. This introduction produced the cross-breed between Farta and Washera breeds. All the study animals were managed extensively and the data were collected under farmer management system.

\section{Data collection and management}

Purposive sampling technique was used to select the two districts, six kebeles (kebele is the smallest administrative unit in Ethiopia) and farmers based on the accessibility of those sheep breed populations and the willingness of sheep owners to participate in the study. Data were generated by monitoring 132 lambs from November 2016 to May 2017. The lambs were identified by labeling them using permanent plastic ear tags at birth. Records of birth date, birth weight, birth type, sex of lamb and dam parity were taken within 24 hours from birth. Growth data were taken every month using Salter balance (50 kg capacity with 200 -gram precision) up to weaning age. 


\section{Statistical analysis}

Preliminary data analysis such as normality test and screening of outliers were employed before conducting the main data analysis. The performance of lambs including birth weight (BW), adjusted weaning weight (AWW), average daily weight gain (ADWG) from birth to weaning were analyzed using the General Linear Models procedure of SAS 9.1.3 (SAS, 2008). For the growth of lambs, the fixed effects considered were agroecology, breed, parity of dam, sex of lamb, and type of birth. Pre-weaning growth performance was adjusted by the following formula (Inyangala et al., 1992).

Adjusted weaning weight $(\mathrm{kg})=\frac{90 *(W 2-W 1)}{D}+\mathrm{W} 1$

Where W2 stands for weight at a given age, W1 for birth weight and D for number of days between weighing date (W2) and date of birth (W1).

The average daily weight gain (ADWG) was calculated using the following formula: $A D W G=\frac{(W 2-W 1) * 1000}{A}$

Where ADWG stands for Average Daily Weight Gain in grams, W1 for birth weight in $\mathrm{kg}$ and $\mathrm{W} 2$ for weight at a given age in $\mathrm{kg}$ and $\mathrm{A}$ for age in days or days between weighing dates.

The statistical model used to analyze growth and daily weight gain was:

$\mathrm{Y}_{\mathrm{ijkl}}=\mu+\mathrm{S}_{\mathrm{j}}+\mathrm{T}_{\mathrm{k}}+\mathrm{D}_{1}+\mathrm{B}_{\mathrm{i}}+\mathrm{K}_{\mathrm{li}}+\mathrm{e}_{\mathrm{ijkl}}$

Where $Y_{\mathrm{ijkl}}$ stands for the observation at birth weight, weight at one and three months of age; $\mu$ for overall mean; $S_{i}$ for fixed effects of sex of lamb ( $\mathrm{i}=$ male, female); $\mathrm{T}_{\mathrm{j}}$ for fixed effect of birth type $(\mathrm{k}=$ single, twin); $\mathrm{D}_{\mathrm{k}}$ for fixed effect of agro ecology ( $\mathrm{k}=$ high land, midland); $\mathrm{B}$ for fixed effect of breed (l=Farta, Washera, and their cross); $K_{\text {ik }}$ for interaction of breed and agro ecology and $\mathrm{e}_{\mathrm{ijkl}}$ for effect of random error. 


\section{RESULTS AND DISCUSSION}

\section{Birth weight}

The overall least squares mean of birth weight was $2.8 \pm 0.05 \mathrm{~kg}$. This was comparable to birth weight of Sekota sheep (Aemero Yiheyis et al., 2012) and Gumuz sheep (Solomon Abegaz et al., 2011). However, it was larger than Menz sheep (Kassahun Awgichew, 2000; Solomon Gizaw, 2002; Markos Tibbo, 2006). Birth weight of lambs was significantly different between breeds, agroecologies, sexes of lamb and parity of the dam (Table 2). Birth weight was an indicator of the size and vigor of the lamb at the beginning of postnatal development and an important factor influencing later growth. Larger lambs at birth had greater capacity for growth and were more likely to be heavier at weaning (Ayele Abebe et al., 2015). Mean birth weight for Farta breed was $2.7 \pm 0.28 \mathrm{~kg}, 3.1 \pm 0.12$ $\mathrm{kg}$ for Washera and $2.9 \pm 0.06 \mathrm{~kg}$ for their crosses. The current study showed that Washera lambs were heavier than the $2.69 \pm 0.02 \mathrm{~kg}$ birth weight reported by Mengistie Taye et al. (2010) and the $2.6 \pm 0.01 \mathrm{~kg}$ weight reported by Shigdaf Mekuriaw et al. (2013). It also showed that Farta and their crossbreds were heavier than the $2.5 \pm 0.02 \mathrm{~kg}$ and $2.59 \pm$ $0.01 \mathrm{~kg}$, respectively (Shigdaf Mekuriaw et al., 2013). Breed type significantly contributed for the difference in weight, e.g., Washera lambs were larger than Farta lambs. Birth weight of highland the lambs was $3.2 \pm 0.07 \mathrm{~kg}$ and midland lambs was $2.6 \pm 0.21 \mathrm{~kg}$. This might be because of difference in management.

Sex also was a significant source of variation in which the birth weight of male lambs was higher than that of female lambs. Similar reports are available from previous studies (Kassahun Awigchew, 2000; Markos Tibbo, 2006; Mengistie Taye et al., 2010; Solomon Abegaz et al., 2011).

Similarly, parity had a significant effect on birth weight of lambs, again a result reported by previous researchers (Mengistie Taye et al., 2010; Solomon Abegaz et al., 2011; Aemero Yiheyis et al., 2012). This might be because of the fact that the reproductive organs of the first parity ewes were less developed to bear large fetus (Markos Tibbo, 2006). 


\section{Weight at a different age}

Factors affecting weights of Farta, Washera and their crossbred lambs at different ages (weights at one month, two months and three months) are presented in Table 2. The mean weight of a one-month old Farta was $5.6 \pm 0.20 \mathrm{~kg}$, Washera was $6.4 \pm 0.33 \mathrm{~kg}$ and their crossbred lamb was $6.10 \pm 0.75 \mathrm{~kg}$. However, Shigdaf Mekuriaw et al. (2013) reported $5.04 \pm 0.29 \mathrm{~kg}$ for Farta lambs and $7.25 \pm 0.13 \mathrm{~kg}$ for Washera Mengistie Taye et al. (2010) reported $7.10 \pm 0.16 \mathrm{~kg}$. The current crosses, however, were in-line with Shigdaf Mekuriaw et al. (2013) report of $6.17 \pm 0.16 \mathrm{~kg}$.

The breed was a significant source of variation among one-month old lambs. Washera lambs were heavier than Farta lambs whereas crossbreds were not different from either of the two parental breeds. The mean weight of one-month old male was $6.4 \pm 0.32 \mathrm{~kg}$ and female lamb was $5.7 \pm 0.37 \mathrm{~kg}$; male lambs were heavier than females at one-month. Mengistie Taye et al. (2010) and Shigdaf Mekuriaw et al. (2013) reported similar findings. Parity was also a significant source of variation. Parity one had a mean weight of $5.0 \pm 0.49 \mathrm{~kg}$, parity two had $6.3 \pm 0.39 \mathrm{~kg}$, three had $5.8 \pm 0.39 \mathrm{~kg}$, four had $6.5 \pm 0.40 \mathrm{~kg}$ and five had $6.4 \pm 0.36 \mathrm{~kg}$.

Moreover, birth type was found to be a source of significant variation. Single birth had $6.3 \pm 0.28 \mathrm{~kg}$ and multiple births had $5.8 \pm 0.38 \mathrm{~kg}$. Single born lambs were heavier than multiple born lambs. This was due to the fact that single lambs were the only user of their dam. This result was similar to previous reports (Mengistie Taye et al., 2010; Shigdaf Mekuriaw et al., 2013).

Interaction of agroecology with the breed was another important source of variation. Highland Farta was $5.05 \pm 0.25 \mathrm{~kg}$, highland Washera $6.5 \pm 0.30 \mathrm{~kg}$, highland crosses $6.1 \pm 0.56 \mathrm{~kg}$, midland Farta $6.1 \pm 0.28 \mathrm{~kg}$, midland Washera $6.3 \pm 0.58 \mathrm{~kg}$ and midland crosses $5.93 \pm 1.40 \mathrm{~kg}$.

Adjusted weaning weight was $11.9 \pm 0.44 \mathrm{~kg}$, a result almost similar to the report of Aemero Yiheyis et al. (2012) to Sekota Sheep and of Solomon Abegaz et al. (2011) to Gumuz sheep in Metema district. Breed type was 
a significant effect on adjusted weaning weight. Farta weaning weight was $10.9 \pm 0.3 \mathrm{~kg}$, Washera was $13.1 \pm 0.5 \mathrm{~kg}$, and their crosses was $12.2 \pm 1.1 \mathrm{~kg}$. In Washera lambs this result was comparable with $11.78 \pm 0.5 \mathrm{~kg}$ in the on-farm management (Shigdaf Mekuriaw et al., 2013) and $12.42 \pm 0.11 \mathrm{~kg}$ in Washera sheep (Mengistie Taye et al., 2010). The adjusted weaning weight of Washera was heavier than the crossbreed and Farta sheep. The size of their cross-bred lambs, though greater than Farta lambs, was not significant.

Male lambs were $12.3 \pm 0.5 \mathrm{~kg}$ and females $11.5 \pm 0.5 \mathrm{~kg}$. Sex mattered probably because of hormonal difference, whereby males were heavier than female lambs, a result similar to what was reported in the literature (Markos Tibbo, 2006; Solomon Abegaz et al., 2011). The interaction of agroecology with the breed was yet another important source of variation. Highland Farta was $10.4 \pm 0.37 \mathrm{~kg}$, highland Washera $12.9 \pm 0.45 \mathrm{~kg}$, highland crosses $11.6 \pm 0.84 \mathrm{~kg}$, midland Farta $11.4 \pm 0.42 \mathrm{~kg}$, midland Washera $13.2 \pm 0.88 \mathrm{~kg}$, and midland cross sheep were $11.9 \pm 2.1 \mathrm{~kg}$.

Washera lambs had greater weaning weight than their crosses as well as Farta lambs. The former also had significant differences between highland and midland agro-ecologies. Their crosses were greater than the Farta breeds at adjusted weaning weight on highland as well as midland. Among Farta sheep, midland lambs had greater weaning weight than did highland lambs. These results might be due to management.

\section{Pre-weaning daily weight gain}

Pre-weaning growth performance of lambs depends on the inherent genetic potential, the adaptability and mothering ability of ewes. The overall mean and standard error of daily weight gain calculated from birth to 30 days of age was $106.7 \pm 9.20 \mathrm{~g}$. Breed type was a significant effect on pre-weaning daily weight gain calculated from birth to 30 days. Farta was $89.3 \pm 6.4 \mathrm{~g}$, Washera $111.4 \pm 10.5 \mathrm{~g}$, and their crosses $119.3 \pm 5.5 \mathrm{~g}$ (Table 3). 
Table 2. Least-square mean of pre-weaning body weight

\begin{tabular}{|c|c|c|c|c|c|c|c|c|}
\hline \multirow[t]{2}{*}{ Source of variation } & \multicolumn{2}{|c|}{ Birth weight } & \multicolumn{2}{|c|}{ 30-day weight } & \multicolumn{2}{|c|}{ 60-day weight } & \multicolumn{2}{|c|}{$\begin{array}{c}\text { Adjusted weaning } \\
\text { weight }\end{array}$} \\
\hline & $\mathbf{N}$ & $\mathbf{L S M} \pm \mathbf{S E}$ & $\mathbf{N}$ & $\mathbf{L S M} \pm \mathbf{S E}$ & $\mathbf{N}$ & $\mathbf{L S M} \pm \mathbf{S E}$ & $\mathbf{N}$ & $\mathbf{L S M} \pm \mathbf{S E}$ \\
\hline Overall & 132 & $2.8 \pm 0.11$ & 130 & $6.0 \pm 0.29$ & 128 & $9.0 \pm 0.40$ & 128 & $11.9 \pm 0.44$ \\
\hline $\mathrm{CV}$ & & 17.18 & & 23.64 & & 22.54 & & 17.36 \\
\hline $\mathrm{R}^{2}$ & & 0.18 & & 0.31 & & 0.35 & & 0.31 \\
\hline & & & & Agroecology & & & & \\
\hline Highland & 80 & $3.0 \pm 0.08^{\mathrm{a}}$ & 79 & $5.8 \pm 0.24$ & 78 & $9.0 \pm 0.34$ & 78 & $11.6 \pm 0.37$ \\
\hline Midland & 52 & $2.6 \pm 0.19^{b}$ & 51 & $6.1 \pm 0.51$ & 50 & $9.1 \pm 0.71$ & 50 & $12.2 \pm 0.77$ \\
\hline & & & & Breed & & & & \\
\hline Farta & 82 & $2.7 \pm 0.28^{\mathrm{b}}$ & 79 & $5.6 \pm 0.20^{\mathrm{b}}$ & 76 & $8.1 \pm 1.04^{b}$ & 75 & $10.9 \pm 0.30^{b}$ \\
\hline Crosses & 30 & $2.9 \pm 0.06^{\mathrm{ab}}$ & 30 & $6.0 \pm 0.75^{\mathrm{ab}}$ & 30 & $8.5 \pm 0.28^{\mathrm{ab}}$ & 30 & $12.2 \pm 1.1^{\mathrm{ab}}$ \\
\hline Washera & 20 & $3.1 \pm 0.12^{\mathrm{a}}$ & 20 & $6.4 \pm 0.33^{\mathrm{a}}$ & 20 & $10.3 \pm 0.4^{\mathrm{a}}$ & 20 & $13.1 \pm 0.50^{\mathrm{a}}$ \\
\hline & & & & Sex & & & & \\
\hline Male & 78 & $2.9 \pm 0.11^{\mathrm{a}}$ & 76 & $6.4 \pm 0.32^{\mathrm{a}}$ & 75 & $9.5 \pm 0.44^{\mathrm{a}}$ & 75 & $12.3 \pm 0.48^{\mathrm{a}}$ \\
\hline Female & 54 & $2.7 \pm 0.11^{\mathrm{b}}$ & 54 & $5.5 \pm 0.34^{b}$ & 53 & $8.4 \pm 0.47^{b}$ & 53 & $11.5 \pm 0.51^{\mathrm{b}}$ \\
\hline
\end{tabular}




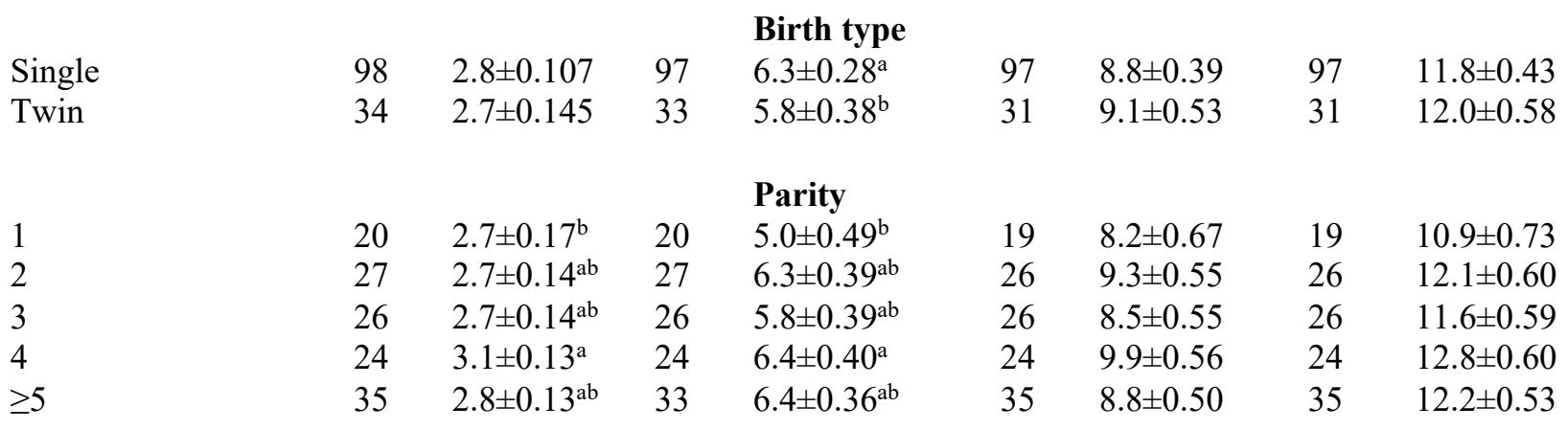

$\begin{array}{lllllllll}\text { Highland*Farta } & 41 & 2.7 \pm 0.09 & 40 & 5.1 \pm 0.25^{\mathrm{b}} & 38 & 7.7 \pm 0.34^{\mathrm{b}} & 37 & 10.4 \pm 0.37^{\mathrm{b}} \\ \text { Highland*Washera } & 13 & 3.1 \pm 0.11 & 11 & 6.5 \pm 0.30^{\mathrm{a}} & 11 & 10.1 \pm 0.40^{\mathrm{a}} & 11 & 12.9 \pm 0.45^{\mathrm{a}} \\ \text { Highland*Cross } & 20 & 2.8 \pm 0.21 & 20 & 6.1 \pm 0.56^{\mathrm{ab}} & 20 & 9.3 \pm 0.39^{\mathrm{a}} & 20 & 11.6 \pm 0.84^{\mathrm{ab}} \\ \text { Midland*Farta } & 35 & 2.8 \pm 0.10 & 35 & 6.1 \pm 0.28^{\mathrm{ab}} & 35 & 9.1 \pm 0.77^{\mathrm{ab}} & 35 & 11.2 \pm 0.42^{\mathrm{ab}} \\ \text { Midland*Washera } & 13 & 3.0 \pm 0.22 & 13 & 6.3 \pm 0.58^{\mathrm{a}} & 13 & 10.4 \pm 0.80^{\mathrm{a}} & 13 & 13.2 \pm 0.88^{\mathrm{a}} \\ \text { Midland*Cross } & 16 & 2.9 \pm 0.52 & 16 & 5.9 \pm 1.40^{\mathrm{ab}} & 16 & 9.5 \pm 1.94^{\mathrm{ab}} & 16 & 11.9 \pm 2.10^{\mathrm{ab}}\end{array}$

$>$ LSM stands for least square means, $\mathrm{N}$ for number of observations; Means with different superscript letters $(\mathrm{a}, \mathrm{b}, \mathrm{c})$ within the same column and class are statistically different at $\alpha=0.05$, means followed by no letters are not significantly different. 
However, Washera lambs had faster growth rate than Farta sheep. Among Washera sheep these results had a value less than what was reported by Mengistie Taye et al. (201), i.e. $143.4 \pm 13.46 \mathrm{~g}$ on the farm management system but a value greater than $84.8 \pm 4.7 \mathrm{~g}$, which was reported by Shigdaf Mekuriaw et al. (2013).

As noted above, sex also had significant effect on daily weight gain of birth to 30 days of age. An average daily weight gain of male was $120.1 \pm 10.1 \mathrm{~g}$ and female lambs was and 93.3 $\pm 10.69 \mathrm{~g}$. Males had a greater growth rate than female lambs. As regards the interaction of agroecology with the breed, another factor with significant source of variation, the result revealed that highland Farta $72.2 \pm 4.86 \mathrm{~g}$, highland Washera 112.2 $\pm 5.52 \mathrm{~g}$, highland Crosses $103.9 \pm 7.63 \mathrm{~g}$, midland Farta $106.5 \pm 8.88 \mathrm{~g}$, midland Washera $110.7 \pm 8.40 \mathrm{~g}$ and midland Crosses $124.8 \pm 13.89$ g. Farta sheep in midland was greater than Farta lamb in highland while Washera lamb in midland was greater than highland lambs, but crosses in midland and highland had no difference.

Overall, birth to weaning age was $101.3 \pm 4.60$ g. Farta sheep was $88.8 \pm 3.21 \mathrm{~g}$, Washera $111.9 \pm 5.22 \mathrm{~g}$, and their crosses $103.2 \pm 11.75 \mathrm{~g}$. Breed type brought about significant effect on weaning weight. Washera lambs showed greater growth performance than did Farta and their cross lambs. This result might be due to breed difference. Among Farta sheep these results were comparable with $83.2 \pm 8.29$, a value reported by Shigdaf Mekuriaw et al. (2013). While the results of Washera sheep were comparable to what was reported by Mengistie Taye et al. (2010), i.e. $107.1 \pm 2.67 \mathrm{~g}$, they were, however, greater than $97.5 \pm 5.01 \mathrm{~g}$, which was reported by Shigdaf Mekuriaw et al. (2013) on-farm management system. Agroecology, on the other hand, had no significant effect. Preweaning daily weight gain from birth to three-month for highland and midland were $95.9 \pm 3.87 \mathrm{~g}$ and $106.7 \pm 8.07 \mathrm{~g}$, respectively. However, sex was a significant source of variation, i.e., growth rate from birth to three months among female and male lambs were 97.0 $\pm 5.34 \mathrm{~g}$ and 105.6 \pm 5.06 $\mathrm{g}$, respectively. Male lambs though showed a faster growth rate than female lambs. 
Table 3. Least squares mean and standard error of pre-weaning average daily weight gain

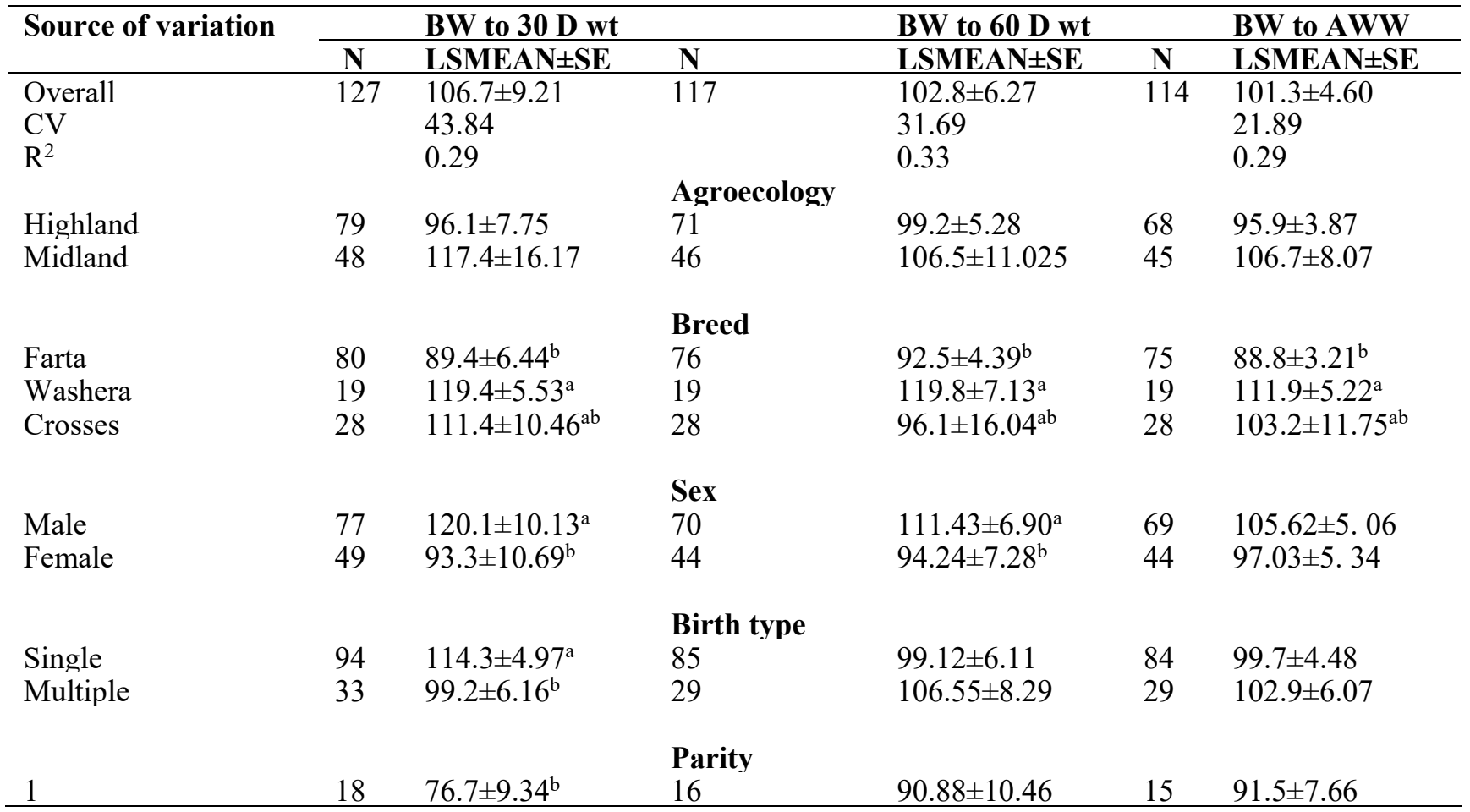




\begin{tabular}{|c|c|c|c|c|c|c|}
\hline 2 & 25 & $121.8 \pm 7.50^{\mathrm{a}}$ & 23 & $111.317 \pm 8.52$ & 23 & $104.4 \pm 6.24$ \\
\hline 3 & 22 & $104.1 \pm 7.42^{\mathrm{ab}}$ & 23 & $97.14 \pm 8.47$ & 23 & $99.4 \pm 6.20$ \\
\hline 4 & 21 & $111.0 \pm 7.62^{\mathrm{ab}}$ & 22 & $113.70 \pm 8.60$ & 22 & $107.2 \pm 6.30$ \\
\hline$\geq 5$ & 31 & $119.8 \pm 6.23^{\mathrm{ab}}$ & 30 & $101.15 \pm 7.65$ & 30 & $104.1 \pm 5.61$ \\
\hline \multicolumn{7}{|c|}{ Agro-ecology*Breed } \\
\hline Highland*Farta & 41 & $72.2 \pm 4.86^{\mathrm{b}}$ & 37 & $80.6 \pm 5.36^{\mathrm{b}}$ & 37 & $83.8 \pm 3.93^{\mathrm{b}}$ \\
\hline Highland*Washera & 13 & $112.2 \pm 5.52^{\mathrm{a}}$ & 11 & $117.1 \pm 6.49^{\mathrm{a}}$ & 11 & $108.5 \pm 4.75^{\mathrm{a}}$ \\
\hline Highland*Cross & 20 & $103.9 \pm 7.63^{\mathrm{ab}}$ & 20 & $100.0 \pm 12.02^{\mathrm{ab}}$ & 20 & $95.4 \pm 8.81^{\mathrm{ab}}$ \\
\hline Midland*Farta & 35 & $106.5 \pm 8.88^{\mathrm{ab}}$ & 35 & $104.5 \pm 6.06^{\mathrm{a}}$ & 35 & $93.8 \pm 4.44^{\mathrm{ab}}$ \\
\hline Midland*Washera & 13 & $110.7 \pm 8.40^{\mathrm{ab}}$ & 13 & $122.6 \pm 12.54^{\mathrm{a}}$ & 13 & $115.2 \pm 9.19^{\mathrm{a}}$ \\
\hline Midland*Cross & 16 & $124.8 \pm 13.89^{\mathrm{ab}}$ & 16 & $102.3 \pm 9.92^{\mathrm{ab}}$ & 16 & $111.0 \pm 11.93^{\mathrm{ab}}$ \\
\hline
\end{tabular}


Interaction of breed with agro-ecology was significant. Daily weight for lambs from birth to weaning age of highland Farta sheep was 83.9 \pm 3.93 g, highland Washera $108.6 \pm 4.75 \mathrm{~g}$, midland crosses $95.4 \pm 8.81 \mathrm{~g}$, midland Farta $93.81 \pm 4.44 \mathrm{~g}$, midland Washera $115.3 \pm 9.19 \mathrm{~g}$ and midland cross sheep $111.0 \pm 21.9$ g. Among Farta sheep, it was midland lambs that showed greater growth performance than highland lambs $(83.9 \pm 3.93 \mathrm{~g}$ vs 93.8 $\pm 4.44 \mathrm{~g})$. Among Washera sheep, however, the highland sheep had greater growth performance than midland lambs whereas among cross lambs, there was no difference for highland and midland agro-ecology.

\section{CONCLUSION}

From the results, it could be concluded that Washera lambs had better birth weight than Farta lambs. There was no significant difference between crossbred lambs of Washera and Farta lambs. Average daily weight gains from birth to 30 days of Washera lambs were greater than that of Farta and their cross. But there is no significant difference between cross lambs of Washera and Farta in average daily weight gain from birth to 30 days and birth to 90 days. The result also indicated that average daily weight gain from birth to 90 days of Washera sheep was greater than that of Farta sheep. These revealed that before we plan to crossbreed programs between the Farta and Washera sheep breeds, we have to undertake selection and make breeding programs based on the performance. Otherwise, crossbreeding without significant differences may lead to genetic admixture among the two breeds.

\section{ACKNOWLEDGEMENTS}

We would like to thank participant farmers in Sekela, Lay Gayint and Farta districts, local agricultural extension agents and district livestock experts for their cooperation during data collection. We would also like to thank Bahir Dar University Biotechnology Institute for funding this research. 


\section{REFERENCES}

Adane Hirpa and Girma Abebe (2008). Economic significance of sheep and goats. In: Yami, A., Merkel, R.C. (Eds), sheep and goat production handbook for Ethiopia. Ethiopia Sheep and Goat Productivity Improvement Program (ESGPIP), Pp: 1-4.

Aemero Yiheyis, Firew Tegegne, Mussie H/Melekot and Mengistie Taye (2012). Pre-weaning growth performance of Sekota sheep breed in Waghimra zone, Ethiopia. Online Journal of Animal and Feed Research 2(4): 340-343

Amha Sebsibe (2008). Sheep and goat meat characteristics and quality. In: Alemu Yami and R.C. Merkel (Eds). Sheep and goat production handbook for Ethiopia. Ethiopian sheep and goats' productivity improvement program (ESGPIP), Addis Ababa Ethiopia. Pp 323-328.

Ayele Abebe, Solomon Gizaw, Asfaw Bisrat, Shenkute Goshme, Shambel Besufekad, Tefera Mekonen, Tesfaye Zewdie and Yeshimebet Chanyalew (2015). Growth performance of Dorper and its F1 crossbreds at Debre-Birhan Agricultural Research Center. Developing Country Studies. ISSN 2224-607X (Paper) Vol.5, No.13.

Burrow, H. M. (2012). Importance of adaptation and genotype $\times$ environment interactions in tropical beef breeding systems. Animal 6(5): 729-740.

CSA (2017). Federal Democratic Republic of Ethiopia Central Statistics Agency, Agricultural Sample Survey 2016/17 (2009 E.C.) Volume II Report on Livestock and Livestock Characteristics (Private Peasant Holdings) statistical bulletin 583 Addis Ababa, Ethiopia.

FAO (2006). Country Pasture/Forage Resource Profiles ETHIOPIA. https://www.scribd.com/document/346403139/FAO-Forage-Profile-Ethiopia 02/01/2019

Gemeda Duguma, Mirkena, T., Haile, A., Iñiguez, L., Okeyo, A. M., Tibbo, M and Wurzinger, M. (2010). Participatory approaches to investigate breeding objectives of livestock keepers. Livestock Research for Rural Development. Volume 22, Article \#64. Retrieved December 17, 2018, from http://www.lrrd.org/lrrd22/4/dugu22064.

Hayes, B.J., Bowman, P.J., Chamberlain, A.J and Goddard, M.E. (2009). Invited review: Genomic selection in dairy cattle: progress and challenges. Journal of Dairy Science 92: 433-43.

Inyangala, B. A. O., Rege, J.E.O and Itulya, S. (1992). Growth traits of the Dorper sheep. I. Factors influencing growth traits. In: Proceedings of the $1^{\text {st }}$ biennial conference on the African Small Ruminant Research Network. ILRAD, Nairobi, Kenya, 10 - 14th December 1990. 505 - 516.

Kassahun Awgichew (2000). Comparative performance evaluation of Horro and Menz sheep of Ethiopia under grazing and intensive feeding conditions. Ph.D. dissertation, Humboldt University, Berlin, Germany.

Kosgey, I.S., Baker, R.L., Udo, H.M.J and van Arendonk, J.A.M. (2006). Successes and failures of small ruminant breeding programs in the tropics: a review. Small Ruminants Research 61: $13-$ 28.

Likawent Yeheyis, Amha Sebsibe and Anteneh Girma (2004). On-farm evaluation of the effect of supplementing grazing Menz sheep during the dry season in Gerakeya Woreda, North Shewa. In Proceedings of the $12^{\text {th }}$ annual conference, August 12-14. Addis Ababa, Ethiopia. Pp: 371-375.

Markos Tibbo, Jan Philipsson and Workneh Ayalew (2006). Productivity and health of indigenous sheep breeds and crossbreds in the central Ethiopian highlands. Ph.D. dissertation. Department of Animal Breeding and Genetics, Faculty of Veterinary Medicine and Animal Sciences, Swedish University of Agricultural Science (SLU), Uppsala, Sweden. Pp 74.

Markos Tibbo (2006). Productivity and health of indigenous sheep breeds and crossbreds in the central Ethiopian highlands. Ph.D. dissertation. Department of Animal Breeding and Genetics, Faculty of Veterinary Medicine and Animal Sciences, Swedish University of Agricultural Science (SLU), Uppsala, Sweden. Pp 74. 
Mengistie Taye, Girma Abebe, Sisay Lemma, Solomon Gizaw, Abebe Mekoya and Markos Tibbo (2011). Reproductive Performances and Survival of Washera Sheep under Traditional Management systems at Yilmana Densa and Quarit Districts of the Amhara National Regional State, Ethiopia. Journal of Animal Science and Veterinary Advances 10(9): 1158-1165.

Mengistie Taye, Girma Abebe, Solomon Gizaw, Sisay Lemma, Abebe Mekoya and Markos Tibbo (2010). Growth performances of Washera sheep under smallholder management systems in Yilmana Densa and Quarit districts, Ethiopia. Tropical Animal Health and Production 42(4): 659667.

Mesfine Lakew, Mussie Haile-Melekot and Getenet Mekuriaw (2014). Evaluation of growth performance of local and Dorper $\times$ local crossbred sheep in eastern Amhara region, Ethiopia. Iranian Journal of Applied Animal Science 4(4): 787-794.

SAS Institute Inc. (2008). SAS/STAT 9.1.3 user's guide. SAS Institute Inc., Cary, NC, USA.

Shigdaf Mekuriaw, Mekuriaw Z., Taye M., Mekuriaw G., Amane A., Bimrew T and Haile A. (2013). Growth performance and linear body measurements of Washera, Farta and their crossbreed sheep under farmers' management system in Western Highland of Amhara Region. Scientific Journal of Veterinary Advances 2(9):132-143.

Solomon Abegaz, Hegde, B.P and Menegistie Taye (2011). Growth and physical body characteristics of Gumuz sheep under traditional management systems in Amhara Regional State, Ethiopia. Livestock Research for Rural Development. Volume 23, Article \#117. Retrieved December17, 2018, from http://www.lrrd.org/lrrd23/5/abeg23117.htm.

Solomon Bogale, Solomon Melaku and Alemu Yami, 2008. Matching livestock systems with available feed resources in the Bale Highlands of Ethiopia. Outlook Agricultural Journal 37: 105110.

Solomon Gizaw and Tesfaye Getachew (2009). The Awassi $\times$ Menz sheep crossbreeding project in Ethiopia: Achievements, challenges, and lessons learned. In: Proceedings of the mid-term conference of the Ethiopian sheep and goat productivity improvement program (ESGPIP), 13-14 March 2009, Hawassa, Ethiopia. Addis Ababa: EGSPIP. Pp. 53-62.

Solomon Gizaw, Azage Tegegne, Berhanu Gebremedhin and Dirk Hoekstra (2010). Sheep and goat production and marketing systems in Ethiopia: Characteristics and strategies for improvement. Improving Productivity and Market Success of Ethiopian Farmers Project Working Paper 23. International Livestock Research Institute, Nairobi, Kenya. Pp 58.

Solomon Gizaw, Komen, H., Hanotte, O and van Arendonk, J.A.M. (2008). Indigenous sheep resources of Ethiopia: Types, production systems, and farmers' preferences. Animal Genetic Resources Information 43:25-40.

Solomon Gizaw, Solomon Abegaz, Rischkowsky, B., Haile, A., Okeyo, A.M and Dessie, T. (2013). Review of sheep research and development projects in Ethiopia. ILRI (aka ILCA and ILRAD).

Solomon Gizaw, Yani A and Kassahun Awigchew (2011). A practical guide on village-based cooperative sheep breeding schemes. Ethiopian sheep and goat productivity improvement program (EGSPIP) Technical Bulletin No. 40. Addis Ababa: EGSPIP.

SPS- LMM (Ethiopia Sanitary and Phytosanitary Standards and Livestock, Meat Marketing Program) (2010). Focus on Ethiopia's meat and live animal export. Trade Bulletin 2, September 2010.

Tesfaye Getachew, Sisay Lemma, Solomon Gizaw and Ayele Abebe (2009). Assessment of adaptability and productivity of Washera rams and it's Crosses in the Highlands of Eastern Amhara Region of Ethiopia. Proceedings of the $4^{\text {th }}$ Annual Regional Conference on Completed Livestock Research Activities. 14 to 16 September 2009. 